\title{
MENINGKATKAN HASIL BELAJAR MATA PELAJARAN PPKN MENGGUNAKAN METODE CREATIVE PROBLEM SOLVING DI KELAS XI MIA 2 SMAN 1 KUBU
}

\author{
Heni Widiastuti \\ Guru PPKn SMA Negeri 1 Kubu, Kabupaten Kubu Raya \\ Email: heni_aja@yahoo.com
}

\begin{abstract}
Abstrak
Tujuan penelitia ini adalah untuk mengetahui penerapan Metode Creative Problem Solving dalam meningkatkan hasil belajar siswa pada mata pelajaran Pendidikan Kewarganegaraan di kelas XI MIA 2 SMAN 1 Kubu. Secara khusu tujuan penelitian ini adalah untuk mengetahui pelaksanaan Model Creative Problem Solving pada mata pelajaran pendidikan kewarganegaraan di kelas XI MIA 2 SMAN 1 Kubu dan untuk mengetahui peningkatan hasil belajar siswa setelah penerapan Metode Creative Problem Solving pada mata pelajaran pendidikan kewarganegaraan di Kelas XI MIA 2 SMAN 1 Kubu. Variabel dalam penelitian ini adalah variabel tindakan dan variabel hasil. Variabel tindakan dalam penelitian ini adalah Metode Creative Problem Solving. Menurut Osborn (Miftahul Huda 2013: 297) "Creative Proble Solving adalah metode untuk menyelesaikan masalah secara kreatif sadangkan variabel hasil dalam penelitian ini adalah hasil belajar. Teknik pengupul data yang dilakukan pada penelitian ini adalah teknik observasi langsung, teknik pengukuran dan teknik dokumenter. Secara khusus dapat ditarik kesimpulan sebagai berikut: Pelaksanaan metode creative problem solving pada mata pelajaran Pendidikan Pancasila dan Kewarganegaraan di kelas XI MIA 2 SMAN 1 Kubu sudah tergolong baik, karena proses pembelajaran berjalan sesuai dengan rencana pelaksanaan pembelajaran (RPP), materi yang disajikan guru menarik perhatian siswa, langkah-langkah metode creative problem solving, sehingga aktivitas siswa dalam bertanya dan menjawab mulai terlatih dan siswa berani untuk mengeluarkan pendapatnya dalam menjawab pertanyaan yang diberikan dan hasil belajar siklus I dan siklus II terdapat peningkatan hasil belajar sebesar 83,35 \% dengan kategori interpretasi tinggi.
\end{abstract}

Kata Kunci: Hasil Belajar, Metode Creative Problem Solving

\begin{abstract}
The purpose of this research is to find out the application of the Creative Problem Solving Method in improving student learning outcomes in Citizenship Education subjects in class XI MIA 2 of SMAN 1 Kubu. Specifically the purpose of this study was to determine the implementation of the Creative Problem Solving Model on citizenship education subjects in the XI MIA 2 class of SMAN 1 Kubu and to find out the improvement in student learning outcomes after the application of the Creative Problem Solving Method on civic education subjects in Class XI MIA 2 SMAN 1 Kubu. Data collection techniques carried out in this study were direct observation techniques and measurement technique. Specifically, the following conclusions can be drawn: The implementation of the creative problem solving method in the subject of Pancasila and Citizenship Education in class XI MIA 2 of the SMAN 1 Kubu is already good, because the learning process runs in accordance with the lesson plan (RPP), the material presented the teacher attracts the attention of students, the steps of the creative problem solving method, so that the students activity in asking and answering begins to be trained and students are brave to express their opinions in answering questions and learning outcomes in cycle I and cycle II there are $83.35 \%$ increase in learning outcomes with high interpretation categories.
\end{abstract}

Keywords: Learning Outcomes, Creative Problem Solving

\section{PENDAHULUAN}

Pendidikan di lingkungan persekolahan merupakan penyelenggaraan sebuah proses pembelajaran yang melibatkan interaksi antara guru dan peserta didik, interaksi tersebut terjadi sebagai usaha untuk mengembangkan kemampuan peserta didik. Berdasarkan ketentuan yang telah ditetapkan dalam Undang-Undang Nomor 20 tahun 2013 tentang Sistem Pendidikan Nasional, disebutkan bahwa, "pendidikan adalah usaha sadar dan terencana untuk mewujudkan 
suasana belajar dan proses pembelajaran agar peserta didik secara aktif mengembangkan potensi dirinya untuk memilih kekuatan spiritual keagamaan, pengendalian diri, kepribadian, kecerdasan, akhlak mulia, serta keterampilan yang diperlukan dirinya, masyarakat, bangsa dan negara".

Untuk memenuhi tuntutan dari tujuan pendidikan nasional tersebut, merupakan sebuah kewajiban bagi seorang guru untuk melakukan inovasi-inovasi yang produktif dalam mengembangkan proses pembelajaran yang benar-benar dapat memberikan pengalaman belajar kepada setiap peserta didik, sehingga akan memberikan dampak terhadap peningkatan hasil dan kualitas belajarnya. Proses belajar dan pembelajaran yang berkualitas dewasa ini selalu dikaitkan dengan sebuah proses interaktif antara guru dan siswa yang dapat menunjukkan kreativitas proses memformulasikan pengetahuan dengan pengalaman secara kreatif sehingga dapat menghasilkan suatu pemikiran yang baru atau mutakhir. Salah satu motode pembelajaran yang dapat memberikan pengaruh positif terhadap kemampuan berpikir kreatif siswa adalah metode creative problem solving ditandai dengan adanya kreativitas yang menjadi kemampuan dasarnya dengan hal ini, menurut Guilford dalam Suryosubroto (2009: 198) bahwa "kemampuan kreatif dapat dicerminkan melalui beberapa prilaku". Selain prilaku kreatif, maka hal lain yang perlu diperhatikan adalah langkah-langkah dalam metode strategi Creative Problem Solving. Penerapan Metode Creative Problem Solving diharapkan siswa dapat menghadapi masalah kelompok untuk dipecahkan bersama-sama dan pada akhirnya hasil belajar yang optimal dari proses pembelajaran tersebut dapat tercapai

Berkenaan dengan strategi pembelajaran Creative Problem Solving, Suryosubroto, (2009: 189) menyatakan bahwa permasalahan-permasalahan atau hambatan yang berkaitan dengan proses pembelajaran dapat disebabkan oleh berbagai komponen. Komponen-komponen pemebelajaran tersebut adalah kemampuan peserta didik dalam pengajaran (pendidik), pihak yang diberi materi pembelajaran (siswa), bahan yang diajarkan (bahan ajar), proses pembelajaran (strategi, metode, teknik mengajar), sarana dan prasana belajar, serta sistem evaluasi yang diterapkan. Masingmasing komponen tersebut saling mempengaruhi dalam upaya pencapaian tujuan pembelajaran.

Kesesuai latar belakang masalah yang dihadapi guru terhadap fenomena kecenderungan hasil belajar siswa yang menurun, opini terhadap pelaksanaan pembelajaran mata pelajaran PPKn yang cenderung monoton dan menuntut siswa hanya mendengarkan penjelasan guru dan mencatat apabila disuruh untuk mencatat sehingga sebagian besar siswa tidak memperhatikan pada saat guru menjelaskan dan siswa kurang bersemangat dalam mengikuti proses pembelajaran, hal tersebut mengakibatkan siswa kurang terlibat aktif dalam proses pembelajaran. Penerapan metode pembelajaran yang kurang sesuai dapat menimbulkan kebosanan, siswa kurang paham dengan materi pelajaran dan monoton sehingga siswa kurang termotivasi untuk belajar. Oleh karena itu 
perlu dilakukan tindakan cermat dengan merubah metode mengajar biasa dengan mengajar menggunakan metode pembelajaran terutama yang banyak melibatkan siswa aktif. Penelitian ini dilakukan untuk meningkatkan hasil belajar mata pelajaran PPKn menggunakan Metode Creative Problem Solving di kelas XI MIA 2 SMAN 1 Kubu.

\section{METODE}

Persiapan sebelum Penelitian tindakan kelas (PTK) dilaksanakan dan di buat berbagai instrumen yang akan digunakan untuk memberikan perlakuan dalam PTK, yaitu: 1) Peneliti melakukan analisis kurikulum untuk mengetahui Kompetensi Dasar (KD) yang akan disampaikan kepada siswa dalam pelajaran Pendidikan kewargamegaraan. 2) Peneliti menyiapkan perangkat pembelajaran yang berupa lembar pengamatan siswa berupa angket dan lembar evaluasi. 3) Peneliti melakukan tes formatif kepada siswa utuk mengetahui pemahaman siswa terhadap materi yang telah disampaikan. Subjek penelitian ini adalah siswa kelas XI MIA 2 SMAN 1 Kubu yang berjumlah 34 orang terdiri dari 21 orang siswa perempuan dan 13 orang siswa laki-laki. Guru sebagai kolaborator yang mengajar mata pelajaran PPKn menggunakan Metode Creative Problem Solving. Teknik pengumpulan data dalam penelitian ini, meliputi: observasi langsung, pengukuran. Untuk melakukan analisis data, penelitian ini menggunakan analisa nilai pesentase ketuntasan belajar siswa.

\section{HASIL DAN PEMBAHASAN}

Hasil penelitian yang diperoleh mengacu pada masalah penelitian, selanjutnya peneliti melakukan pengumpulan data dengan menggunakan teknik observasi langsung dengan panduan observasi dan pengumpulan data menggunakan teknik pengukuran dengan test formatif. Setelah Penerapan metode creative problem solving siklus I dan II dilaksanakan, dilanjutkan dengan refleksi untuk membahas hasil observasi. Tujuan dari observasi dalam penelitian ini adalah untuk mengetahui dan memperoleh gambaran lengkap secara objektif tentang perkembangan proses dan pengaruh tindakan yang dipilih terhadap pembelajaran yang dilakukan pengajar dalam menyampaikan materi Sistem dan Dinamika Demokrasi Pancasila. Menggunakan metode Creative Problem Solving secara lengkap observasi sebagai berikut:

1) Guru dalam menyampaikan materi terlalu serius, sehinga menyebabkan siswa tegang yang berakibat pada konsentrasi siswa cendrung berkurang karena siswa terkesan takut.

2) Guru dalam menyajikan materi masih kurang menarik perhatian siswa, dapat dilihat dai keaktifan siswa dalam bertanya ataupun menjawab kurang terlatih dan terlihat siswa kurang 
berani untuk mengeluarkan pendapatnya masing-masing baik dalam penyampaian materi maupun dalam menjawab pertanyaan-pertanyaan yang diberikan.

3) Dalam proses kegiatan pembelajaran, guru kurang mendorong semangat belajar siswa melalui tanya jawab pada saat proses pembelajaran berlangsung, sehingga guru kurang berinteraksi antara siswa.

4) Guru tidak meminta siswa untuk bersama-sama menyimpulkan tentang materi yang telah dipelajari. Untuk selanjutnya dilakukan evaluasi yang berupa tes tertulis.

Adapun hasil evaluasi dari tes tertulis bisa dilihat di table 1.1

Tabel 1.1 Hasil Belajar siswa Siklus I

\begin{tabular}{|c|c|c|c|}
\hline NO & Nama & Nilai & Ketuntasan \\
\hline 1. & Adityansyah & 78 & Tuntas \\
\hline 2. & Afina & 78 & Tuntas \\
\hline 3. & Bagus Hermawan & 71,5 & Tidak Tuntas \\
\hline 4. & Dhea Purwati & 78 & Tuntas \\
\hline 5. & Dian Agus Setiawan & 65 & Tidak Tuntas \\
\hline 6. & Doni Triadi & 78 & Tuntas \\
\hline 7. & Evi Mayasari & 84,5 & Tuntas \\
\hline 8. & Fiqhi Firmansyah & 71,5 & Tidak Tuntas \\
\hline 9. & Heri Yansyah & 71,5 & Tidak Tuntas \\
\hline 10. & Herlianto & 78 & Tuntas \\
\hline 11. & Indra Dwi Kurniawan & 71,5 & Tidak Tuntas \\
\hline 12. & Ita Elviana & 84,5 & Tuntas \\
\hline 13. & Lenny Lestari & 78 & Tuntas \\
\hline 14. & Lina Asiska & 65 & Tidak Tuntas \\
\hline 15. & Muhammad Syafar & 71,5 & Tidak Tuntas \\
\hline 16. & Melfi Meldia & 84,5 & Tuntas \\
\hline 17. & Michael Timotius & 78 & Tuntas \\
\hline 18. & Mutiara Arum Safitri & 78 & Tuntas \\
\hline 19. & Nindrum Sulistio & 84,5 & Tuntas \\
\hline 20. & Noga Ardianto & 65 & Tidak Tuntas \\
\hline 21. & Pitri Eliani Siregar & 71,5 & Tidak Tuntas \\
\hline 22. & Putri Emelia Lestari & 78 & Tuntas \\
\hline 23. & Ridho Hadienata & 84,5 & Tuntas \\
\hline 24. & Riky Sutansyah & 65 & Tidak Tuntas \\
\hline 25. & Sania & 71,5 & Tidak Tuntas \\
\hline 26. & Sonia Ilana & 71,5 & Tidak Tuntas \\
\hline 27. & Surya Dwi Prasetya & 84,5 & Tuntas \\
\hline 28. & Suryadi & 71,5 & Tidak Tuntas \\
\hline 29. & Syahrul Diki Saputra & 78 & Tuntas \\
\hline 30. & Taufik Hidayat & 84,5 & Tuntas \\
\hline 31. & Titi Indriati & 71,5 & Tidak Tuntas \\
\hline 32. & Veby Dea Astuti & 65 & Tidak Tuntas \\
\hline 33. & Vikry Maulidy Almahdi & 78 & Tuntas \\
\hline
\end{tabular}




\begin{tabular}{llcc}
\hline 34 & Wulandari Purnama Ningsih & 84,5 & Tuntas \\
\hline Jumlah Skor/Nilai & 2574 & \\
\hline Rata-Rata & 75,71 & \\
\hline
\end{tabular}

Sumber: Rekap Hasil Evaluasi Siklus 1

Dari tabel diatas dapat dilihat perkembangan hasil belajar siswa saat diberikan post test pada pra siklus dan post test siklus I. Pada siklus I siswa yang memperoleh ketuntatasan belajar atau memperoleh nilai ketuntasan pada siklus 1 sekitar 19 orang siswa dengan presentase ketuntasan klasikal 55,88\%. Berdasarkan data hasil belajar pada tindakan siklus 1 diatas dapat diketahui bahwa pemahaman hasil belajar siswa yang diperoleh dari tes hasil belajar terdapat 19 orang siswa yang tuntas $(55,88 \%)$, sedangkan 15 orang siswa yang belum tuntas $(44,12 \%)$, dengan nilai rata-rata kelas 75,71. Dengan kriteria ketuntasan minimum (KKM) 75. Selanjutnya berdasarkan hasil perhitungan persentase terhadap hasil belajar siswa pada siklus I diperoleh nilai 55,88 \% termasuk kategori interpretasi rendah, hal tersebut mengindikasikan bahwa hasil belajar siswa pada materi Sistem dan Dinamika Demokrasi Pancasila menggunakan metode Creative Problem Solving dikelas XI MIA 2 SMAN 1 Kubu belum mencapai indikator yang ditentukan untuk keberhasilan belajar yaitu $75 \%$.

Merujuk pada hasil belajar siswa pada siklus I tersebut, maka dilakukan perbaikanperbaikan proses pengajaran yang dilakukan pada siklus II. Adapun hasil pengajaran pada siklus II di uraikan sebagai berikut:

1. Dilihat dari fase 1 pada siklus II, guru dalam dalam menjelaskan materi sudah mulai maksimal, hal ini dapat dilihat pada kegiatan pada saat proses pembelajaran siswa sudah mulai aktif dan siswa mengikuti proses belajarpun tidak tegang karena adanya komunikasi antara siswa dan guru, sehingga hal ini membuat siswa lebih mudah untuk memahami materi yang disampaikan.

2. Guru sudah menemukan teknik dalam menumbuhkan semangat belajar siswa yaitu dengan cara memberikan apresiasi sehingga siswa terkesan bersemangat untuk belajar yang berdampak pada perkembangan kemampuan berpikir kritis siswa.

3. Guru memberikan dorongan kepada siswa untuk meransang pola pikir siswa dengan cara memberikan suatu fakta permasalahan yang berkaitan dengan materi sistem dan dinamika demokrasi pancasila untuk lebih berani berargumen untuk mencari solusi permasalahan tersebut.

4. Pada akhir proses pembelajaran guru bersama siswa untuk menyimpulkan materi yang telah disampaikan, agar dapat melihat sejauh mana siswa memahami materi yang telah disampaikan. 
Adapun hasil evaluasi dari tes tertulis bisa dilihat pada tabel 1.2

Tabel 1.2 Hasil Belajar siswa Siklus II

\begin{tabular}{|c|c|c|c|}
\hline NO & Nama & Nilai & Ketuntasan \\
\hline 1. & Adityansyah & 84,5 & Tuntas \\
\hline 2. & Afina & 91 & Tuntas \\
\hline 3. & Bagus Hermawan & 78 & Tuntas \\
\hline 4. & Dhea Purwati & 84,5 & Tuntas \\
\hline 5. & Dian Agus Setiawan & 84,5 & Tuntas \\
\hline 6. & Doni Triadi & 84,5 & Tuntas \\
\hline 7. & Evi Mayasari & 91 & Tuntas \\
\hline 8. & Fiqhi Firmansyah & 78 & Tuntas \\
\hline 9. & Heri Yansyah & 65 & Tidak Tuntas \\
\hline 10. & Herlianto & 78 & Tuntas \\
\hline 11. & Indra Dwi Kurniawan & 78 & Tuntas \\
\hline 12. & Ita Elviana & 84,5 & Tuntas \\
\hline 13. & Lenny Lestari & 84,5 & Tuntas \\
\hline 14. & Lina Asiska & 71,5 & Tidak Tuntas \\
\hline 15. & Muhammad Syafar & 78 & Tuntas \\
\hline 16. & Melfi Meldia & 84,5 & Tuntas \\
\hline 17. & Michael Timotius & 78 & Tuntas \\
\hline 18. & Mutiara Arum Safitri & 84,5 & Tuntas \\
\hline 19. & Nindrum Sulistio & 91 & Tuntas \\
\hline 20. & Noga Ardianto & 71,5 & Tidak Tuntas \\
\hline 21. & Pitri Eliani Siregar & 84,5 & Tuntas \\
\hline 22. & Putri Emelia Lestari & 84,5 & Tuntas \\
\hline 23. & Ridho Hadienata & 91 & Tuntas \\
\hline 24. & Riky Sutansyah & 78 & Tuntas \\
\hline 25. & Sania & 78 & Tuntas \\
\hline 26. & Sonia Ilana & 71,5 & Tidak Tuntas \\
\hline 27. & Surya Dwi Prasetya & 84,5 & Tuntas \\
\hline 28. & Suryadi & 71,5 & Tidak Tuntas \\
\hline 29. & Syahrul Diki Saputra & 78 & Tuntas \\
\hline 30. & Taufik Hidayat & 91 & Tuntas \\
\hline 31. & Titi Indriati & 91 & Tuntas \\
\hline 32. & Veby Dea Astuti & 71,5 & Tidak Tuntas \\
\hline 33. & Vikry Maulidy Almahdi & 91 & Tuntas \\
\hline \multirow[t]{3}{*}{34} & Wulandari Purnama Ningsih & 78 & Tuntas \\
\hline & Jumlah Skor/Nilai & 2769 & \\
\hline & Rata-Rata & 81,44 & \\
\hline
\end{tabular}

Sumber: Rekap Hasil Evaluasi Siklus II

Dari tabel diatas dapat dilihat hasil tindakan siklus II menunjukan bahwa hasil belajar siswa melalui evaluasi terdapat 28 orang siswa tuntas $(82,35 \%)$, sedangkan siswa belum tuntas 6 orang $(17,65 \%)$. Dengan nilai rata-rata kelas meningkat menjadi 81,44. Nilai siswa terendah 65 sedangkan nilai siswa tertinggi 91. Dengan kriteria ketuntasan minimum (KKM) 75. Berdasarkan 
hasil perhitungan rumus persentase bernilai 82,35 \% termasuk kategori interpretasi tinggi menunjukan bahwa hasil belajar siswa pada materi Sistem dan Dinamika Demokrasi Pancasila menggunakan metode Creative Problem Solving di kelas XI MIA 2 SMAN 1 Kubu sudah mencapai indikator yang ditentukan untuk keberhasilan belajar yaitu $75 \%$.

Proses pembelajaran yang mengalami perubahan-perubahan kearah yang lebih baik pada Penerapan metode creative problem solving setelah 2 siklus dapat meningkatkan hasil belajar siswa pada pelajaran Pendidikan Pancasila dan Kewarganegaraan. Pelaksanaan metode creative problem solving pada mata pelajaran PPKn di kelas XI MIA 2 SMAN 1 Kubu tergolong baik, karena proses pembelajaran berjalan sesuai dengan rencana pelaksanaan pembelajaran (RPP), materi yang disajikan guru menarik perhatian siswa, langkah-langkah metode creative problem solving, sehingga aktivitas siswa dalam bertanya dan menjawab mulai terlatih dan siswa berani untuk mengeluarkan pendapatnya dalam menjawab pertanyaan yang diberikan dan berdasarkan hasil belajar siklus I dan siklus II terdapat peningkatan hasil belajar sebesar 83,35 \% dengan kategori interpretasi tinggi.

Penelitian tindakan kelas ini dapat dikatakan berhasil, melihat dari gambar dibawah ini terjadi peningkatan hasil belajar baik dari nilai rata-rata kelas, ketuntasan klasikal maupun berdasarkan peningkatan jumlah siswa yang tuntas.

\section{Grafik 1 Presentase Ketuntasan Hasil Belajar Siswa}

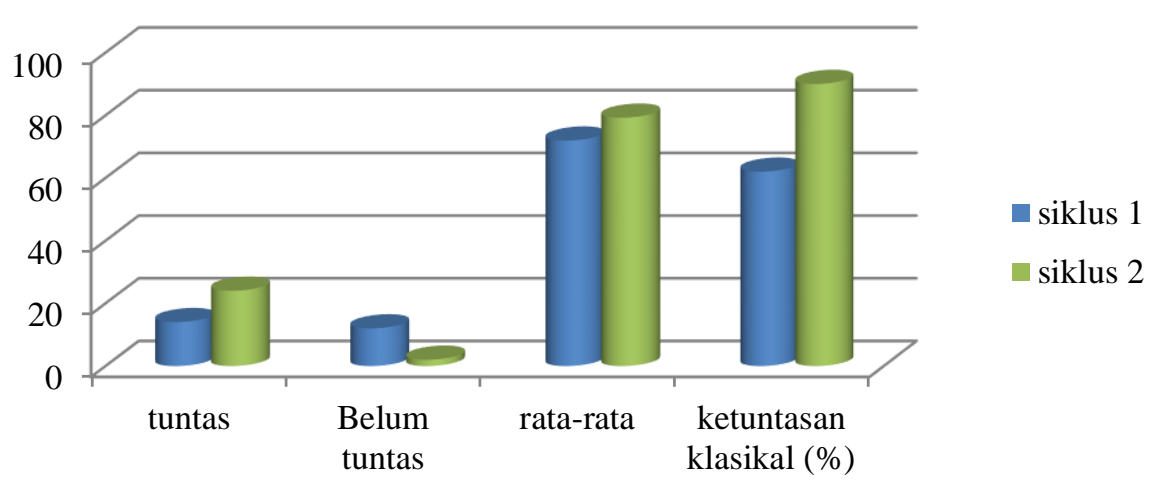

Penelitian tindakan kelas ini dapat dikatakan berhasil, melihat dari gambar presentase grafik diatas terjadi peningkatan hasil belajar baik dari nilai rata-rata kelas, ketuntasan klasikal, maupun berdasarkan peningkatan jumlah siswa yang tuntas. Hasil tersebut menunjukkan bahwa terjadi peningkatan nilai rata-rata dan ketuntasan klasikal hasil belajar terlihat dari siklus I dan siklus II.

\section{SIMPULAN}

Berdasarkan hasil penelitian, Pelaksanaan metode creative problem solving pada mata pelajaran Pendidikan Pancasila dan Kewarganegaraan di kelas XI MIA 2 SMAN 1 Kubu tergolong baik, karena proses pembelajaran berjalan sesuai dengan rencana pelaksanaan pembelajaran (RPP), 
materi yang disajikan guru menarik perhatian siswa, baiknya hasil belajar yang diperoleh siswa tidak terlepas dari usaha guru dalam menerapkan langkah-langkah metode creative problem solving, sehingga aktivitas siswa dalam bertanya dan menjawab mulai terlatih dan siswa berani untuk mengeluarkan pendapatnya dalam menjawab pertanyaan yang diberikan dan berdasarkan hasil belajar siklus I dan siklus II terdapat peningkatan hasil belajar sebesar 83,35 \% dengan kategori interpretasi tinggi.

\section{DAFTAR PUSTAKA}

Aris Shoimin (2017). 68 Model Pembelajaran Inovatif dalam Kurikulum 2013. Yogyakarta. ARRUZZ MEDIA

Aunurrahman (2012). Belajar dan Pembelajaran. Bandung: Alfabeta

Hamid Darmadi (2012). Pengantar Pendidikan Kewarganegaraan. Bandung: Alfabeta

Herlina, (2015). Pengaruh Penerapan Metode Creative Problem Solving Oleh Guru Pendidikan Kewarganegaraan Terhadap Hasil Belajar Siswa Kelas X Sekolah Menengah Atas Negara 1 Sengah Temila Kabupaten Landak. Skripsi Sarjana Pada IKIP-PGRI Pontianak: Tidak diterbitkan

Huda, M. (2013). Model-Model Pengajaran dan Pembelajran Isu-Isu Metodis dan Paradigmatis. Yogyakarta: Pustaka Belajar.

Jakni (2014). Pendidikan Kewarganegaraan di Perguruan Tinggi. Bandung. Alfabeta.

Karunia Eka Lestari dan Mokhammad Ridwan Yudhanegara (2015). Penelitian Pendidikan Matematika. Bandung. PT Refika Aditama.

Kunandar (2013). Langkah Mudah Penelitian Tindakan Kelas Sebagai Pengembangan Profesi Guru. Jakarta. PT. Raja Grafindo Persada.

Miftahul Huda (2013). Model-Model Pengajaran dan Pembelajaran. Yogyakarta: Pustaka Pelajar Paizaluddin dan Ermalinda (2014). Penelitian Tindakan Kelas. Bandung. Alfabeta

Rochiati Wiriaatmadja (2005). Metode Penelitian Tindakan Kelas. Bandung: PT Remaja Rosdakarya

Slameto. (2010). Belajar dan Faktor-Faktor yang Mempengaruhinya. Jakarta. PT. Rineka Cipta.

Sudarwan Danim (2010). Pengantar Kependidikan Bandung: Alfabeta

Sudaryono (2012). Dasar-Dasar Evaluasi Pembelajaran. Yogyakarta, Graha Ilmu

Zuldafrial (2012). Evaluasi Pendidikan dan Penelitian Tindakan Kelas. Pontianak: STAIN Pontanak Press 